\title{
Czeglédi Pál* \\ Klasszikus és keresztény erények a gazdasági növekedés szolgálatában
}

(McCloskey, Deirdre N.: Bourgeois Virtues: Ethics for an Age of Commerce. The University of Chicago Press, Chicago and London, 2006, 616 oldal)

Deirdre McCloskey nem szokványos sztárközgazdász. Az, hogy a harvardi doktorátus után a Chicagói Egyetemen dolgozott és lett sikeres Robert Fogel munkatársaként a kliometria területén, még nem mond semmit. De McCloskey tudományos felfogása egy idő után gyökeres fordulatot vett, s e fordulatot sokféleképpen meg lehetne fogalmazni, de talán a legegyszerübb, ha azt mondjuk, hogy elfordult a pozitivista állásponttól (McCloskey 1989), és ezzel egy időben a Chicagói Egyetemről is távozott. A közgazdaságtan retorikájáról kezdett írni, és a közgazdaságtan bevett módszereinek egyik leginkább komolyan vehetö, és konstruktív kritikusává vált, a szokásostól elütő kritikai érveket fogalmazva meg (McCloskey 2002). Sem a chicagói közgazdaságtannak, sem a kliometriának nem fordított azonban hátat. Nem tartozik tehát a „mainstream” közgazdaságtan szokásos, laikus kritikusai közé, két okból sem. Egyrészt azért nem, mert a lehető legmagasabb színvonalú tudással rendelkezik arról, amit kritizál. Másrészt, kritikája valóban konstruktív, amit jól példáz eddigi munkássága, többek között ez a könyv is, amely a 90-es években megkezdett, a piacgazdaság etikai alapjaira vonatkozó kutatásának (McCloskey 1994) az eredménye.

A 2006-ban megjelent Bourgouies Virues című könyvében ugyanakkor McCloskey nem marad hütlen másik két fő kutatási területéhez, a gazdaságtörténethez és a retorikához sem. A Bourgeois Virtues csak az első kötete annak a négy kötetesre tervezett munkának, amelynek fö állítása az, hogy a modern gazdasági növekedés alapvetően annak a retorikai fordulatnak köszönhetö, amely etikával támasztotta alá a piaci magatartást, vagy, ahogy McCloskey mondja: a „burzsoá életet”. Ennek az etikai a programnak az első alakja Adam Smith volt más 18. századi gondolkodókkal együtt, s ö ehhez a hagyományhoz tér vissza. Azért vissza, mert az értelmiség, a közgazdászokat beleértve, elhagyta az Adam Smith-i programot és különbözö, és - más-más szempontból ugyan, de - azzal ellentétes utakon indultak el. Az Adam Smith-i útról való e korai letérés adja a könyv fö dilemmáját: bár a modern élet egyre inkább „burzsoá, a népesség egyre nagyobb százaléka végez fehérgalléros munkát és él városokban, az etikai gondolkodásunkat még mindig a "plebejus” és az „arisztokrata” etika határozza meg, melyek nehezen egyeztethetök össze a modern keres- 
kedőtársadalom valós müködésével. S mivel 1848 óta (amely a szerző szerint a rossz útra térés szimbolikus évszáma) sok víz lefolyt a Dunán, az Elbán, a Temzén, a Mississippin, és legföképpen a Szajnán, van kivel vitatkoznia, illetve van kit meggyőznie.

De miről is kell meggyőzni és pontosan kit? A szerző a lehető legtömörebben fogalmazva azt állítja, hogy a kapitalizmus nem rossz dolog, és nemcsak azért nem rossz, mert gazdaggá tesz/tett minket, de erkölcsileg sem az: a piac nem csupán erényekre épül, de fenn is tartja azokat. A célközönség tehát az értelmiség: saját bevallása szerint nemcsak a bal-, de az egyébként piacpárti jobboldali értelmiséget is meg akarja győzni. Utóbbi a szerző szerint azért látja helytelenül a piacot, mert azt gondolja, hogy a haszonmaximalizálás logikájával magyarázni lehet a müködését, és ilyen értelemben egy oldalon áll a baloldallal. A szerző tehát kétfajta állásponttal vitatkozik: az egyik szerint a piac elidegenít, elsorvasztja a „régi szép világot”, kiöli az emberekből a szeretetet, becsületet stb., aminek következtében ma már „csak a pénz számít”, és ez katasztrófa. A másik oldalon állók majdnem ugyanezt mondják azzal a kis különbséggel, hogy szerintük mindez nem katasztrófa, mert cserébe jobban élünk, mint bárki bármikor élt a Földön. McCloskey provokatív álláspontja szerint egyik sem igaz: a piac sem nem öli meg az erkölcsöket, sem nem müködhet erényes emberek nélkül.

A könyv hat részre, és negyvennyolc 8-12 oldalas fejezetre oszlik, de három nagyobb logikai egységre különíthető el. Az első háromszáz oldalon a szerző etikai rendszerének építőköveit mutatja be, azaz az általa alapvetőnek gondolt, és a nyugat-európai kultúrában hosszú idő óta jelen lévő erényeket elemzi. Hét erényt különböztet meg, s mindnek a mibenlétét, lényegét, félreértelmezéseit, igazi jelentését fejezeteken keresztül illusztrálja, illetve magyarázza. A hét erényt alapvetően két csoportba sorolja: a keresztény erényeket a szeretet, a hit és a remény jelentik, a pogány erényeket pedig a prudencia, a bátorság mértékletesség és az igazságosság. ${ }^{1}$

A szerző általában több fejezetet is szán arra, hogy egy-egy erény valódi tartalmát megvilágítsa. Nem mindig könnyü követni ezeket az eszmefuttatásokat. Egyrészt azért nem, mert a könyv elöre kitüzött céljának megfelelően folyamatosan vitatkozik valamelyik ellenfelével, ráadásul ellenfelei meglehetősen sokszínűek, de legalább két táborból jönnek. Így McCloskey a fejezetek többségében kétfelé is érvel: egyrészt meg kell mutatnia azt, hogy az általa vizsgált erények nem összeegyeztethetetlenek a piacgazdasági viselkedéssel, másrészt azt is bizonyítania kell, hogy nem is vezethetők le pusztán a haszonmaximalizálásból. Mindez összekapcsolódik az erények mibenlétének magyarázatával. Ez pedig már egy másik oka annak, hogy McCloskey könyve nem könnyü olvasmány. A szerző nem-pozitivista erény-etikájának következménye az, hogy az erényeket nem lehet definiálni, az erények és még inkább az erényes magatartás - csak példákon, történeteken keresztül ismerhető meg, és „minden erény mögött az emberi történetek egy egész könyvtára áll” (327. o.). A szerző ezért számtalan példát, történetet idéz fel, amelyeknek a forrásai a lehető legkülönbözőbbek, ami egyúttal a McCloskey döbbenetes műveltségére is rávilágít. A történelem és az amerikai illetve a holland mindennapok ${ }^{2}$ példáin túl, könnyeden idéz Aquinói Szent Tamástól, Jane Austintól, Robert Nozicktól, Frank Knighttól és Gary Beckertől, a pszichológus Csikszentmihályi Mihálytól, de hollywoodi filmekből is. Erényekről alkotott álláspontja nemcsak az utilitarista nézet elutasításában tér el az „informális intézmények” megszokott

\footnotetext{
1 Love, Faith, Hope, Prudence, Courage, Temperance, Justice

2 McCloskey az Erasmusuniversitait Rotterdamnak is vendégprofesszora.
} 
elemzésétől, de abban is, hogy szerinte ezek az erények nem feltétlenül a másik emberre vonatkoznak, mert néhányuk az emberi identitáshoz tartozik, illetve a transzcendenshez való viszonyt definiálja. A gazdasági következmények tekintetében ez nem mellékes állítás. Ezek szerint az erények gazdasági szerepe nem feltétlenül csak annyi, hogy csökkentik a csere tranzakciós költségeit például a bizalom magasabb szintjén keresztül. Az erények által kialakított etikai rendszer meghatározza azt, hogy mit tart egy társadalom „jónak” azon cselekvések közül, amelyek némelyike gazdasági növekedéshez vezet. A burzsoá etika újdonsága a középkori etikával szemben az, hogy az előbbiben az etikai szempontból jó cselekedetek egybeesnek a gazdasági növekedést megalapozó cselekvésekkel.

Az erények leírása után következő második logikai egységet a könyv negyedik száz oldala jelenti. Itt a szerző a hét erényt rendszerként mutatja be. Ehhez először is megmutatja, hogy milyen dimenziók mentén, és hogyan helyezhetők el. Másodszor, saját erényrendszerét összeveti a múltbeli erényrendszerekkel, és az etikával foglalkozó más szerzők által kialakított hasonló listákkal. Ám leginkább annak szenteli ezt a száz oldalt, hogy meggyőzzön minket arról: ez a hét erény nem redukálható egyetlen erénnyé. Részletes magyarázatát kapjuk annak, hogy a szerző által újjáéleszteni kívánt erény-etika hogyan és miért áll szemben minden olyan megközelítéssel, amely egyetlen szabályra redukálja a jó fogalmát. Így megkapja a magáét Jeremy Bentham az utilitarizmus miatt és vele együtt közgazdaságtan haszonmaximalizálásra épülő imperialista modelljei, Immanuel Kant a kategórikus imperatívuszért, és a kontraktariánus politikai filozófiai megközelítés is. Az etikus magatartásnak nincs egyetlen olyan receptje - mondja McCloskey - amit, ha szükséges, elöránthatunk a zsebünkből. Az etikus magatartás a hét erény egyensúlyát jelenti, ahogy a történelemi értelemben vett burzsoá etika is az erények egy olyan egyensúlya, amely egyértelmüen megkülönböztethető az arisztokrata és a plebejus erényektől, de nem is egyenlö azzal, amit az értelmiség a 19. század közepe óta gondol róla. A burzsoá magatartás sokkal kevésbé jelent pusztán prudenciát, mint azt a burzsoák lázadó gyermekei hajlamosak gondolni: a burzsoá magatartás csak a szolidaritás és a prudencia, a keresztény és pogány erények keverékével érthető meg. A könyv egyik fö - meg nem oldott - rejtélye az, hogy ennek ellenére az európai értelmiség miért utasítja el az erényeknek ezt a rendszerét az arisztokrata és a plebejus erényeket hangsúlyozva. McCloskey legkedvesebb példája a középnyugati amerikai kisváros (Iowa city), amelyen ez értelmiség fintorogni szeret, de amelynek társadalma nem múködhetne csupán a prudenciára alapozva, és nem is úgy müködik, bár a prudencia sem számít itt kevésbé erénynek, mint a bátorság vagy a keresztényi szeretet.

Ekkorra az is világossá válik az olvasó számára, hogy a szerző egyáltalán nem utasítja el a közgazdaságtan prudenciára épülő magyarázatait, de azon a véleményen van, hogy nem alkalmazhatóak ész nélkül: bizonyos kérdések esetén - mint például a gazdasági növekedés okainak kutatása - nem mehetünk el a mellett a nyilvánvaló tény mellett, hogy a prudencia nem az egyetlen motivációja az emberi cselekvésnek. Ezen állítás alátámasztásának szenteli a szerző könyv harmadik logikai egységét. Arról próbálja meggyőzni az olvasót, hogy a szent és a profán a modern életben összekapcsolódik. A kapitalizmuskritika klasszikus érveit veszi elő és mutatja meg, hogy egyik vitatott jelenség mögött sem a puszta kapzsiság áll: a gazdaság „motorja” nem a fogyasztás; a hatalmas vagyonokat szerző vállalkozók nem „rablók”; a munka nemcsak eszköz, hanem cél is egyben, így a munkások nem „rabszolgák”. Igaz, a szerző „posztmodern” megközelítésében a pozitív és a normatív elemzés összemosódik, de ez nem kell, hogy a tények vagy a mérés mellőzését jelentse. Ennek megfelelően minden állítását igyekszik tényekkel alátámasztani. A szerző antipozitivizmusa tehát nem 
a közgazdaságtan kvantitatív módszereinek elutasításában rejlik, csupán annak elismerését jelenti, hogy a mérés a megismerésnek nem az egyetlen módja, így közgazdasági magyarázatainkban sem csak azokat a tényezőket vehetjük figyelembe, amelyeket mérni tudunk.

Az erények rendszere egyszerre jelenti tehát azokat a magatartási motivációkat, amelyek magyarázzák azt, hogy hogyan jöttek létre a piac intézményei és indult be a modern gazdasági növekedés Észak-Nyugat-Európában, és annak a régi, etikai megfontolásokat sem nélkülöző közgazdaságtannak az alapjait, amelyhez a szerző szerint vissza kell térni. A könyv e két provokatív állítása közül az első a kevésbé provokatív, hiszen azt a nézetet, hogy a piacgazdaság pusztán a haszonszerzés vágyára épül már Max Weber (1982:10-11) is gyerekes gondolatnak nevezte. ${ }^{3}$ De az informális intézményeknek és a társadalmi tókének már a tradicionális növekedéselmélet is jelentős szerepet szán. A szerző azonban nem „felülről lefelé" halad az informális intézmények elemzésében, hanem „alulról felfelé”. Nem azért tekinti magyarázó változónak a kulturális tényezőket, mert a többi tényező nem elegendő a magyarázathoz, hanem az egyes - emberi mivoltunknál fogva a priori ismert - erényektől elindulva mutatja meg, hogy azok miként alkothatnak rendszert, és hogyan válhat e rendszer a gazdasági növekedés elősegítőjévé.

A könyv kulcsfogalma tehát a meggyözés. McCloskey egyik kedvenc állítása szerint (483. o, és McCloskey - Klamer 1995) GDP-nek nagyjából a negyede meggyőzés. Ennek a könyvnek a száz százaléka az.

\section{Hivatkozások}

McCloskey, D. N. (1989): Why I am No Longer A Positivist. Megjelent: Ziliak, S. T. (szerk.): Measurement and Meaning in Economics. The Essential Deirdre McCloskey. Edward Elgar, Northampton, MA, USA, 2001, 153-166.

McCloskey, D. N. (1994): Bourgoeis Virtue. American Scholar, 63. évf., 2. sz., 177-191.

McCloskey, D. N. (2002): The Secret Sins of Economics. Prickley Paradigm Press, Chicago.

McCloskey, D. N. - Klamer, A. (1995): One Quarter of GDP is Persuasion. American Economic Review, 85. évf., 2. sz., 191-195.

Weber, Max (1982): A protestáns etika és a kapitalizmus szelleme. Vallásszociológiai írások. Gondolat, Budapest.

3 "A »szerzési ösztönnek", »nyereségvágynak", a lehetöleg magas pénznyereség szándékának önmagában véve semmi köze a kapitalizmushoz. .... E naiv fogalmi társitás a müvelödéstörténet gyerekszobájába való, s végezzünk vele egyszer s mindenkorra" (Weber 1982:10-11). 